Ks. Rafał Dappa

Wydział Teologiczny UŚ w Katowicach

ORCID 0000-0002-1599-6352

\title{
Instytucja zapowiedzi w aktualnym porządku prawnym Kościoła katolickiego w Polsce
}

Treść: Wstęp. 1. Zapowiedzi w Kodeksie Prawa Kanonicznego z 1983 roku. 2.Ochrona danych osobowych. 3. Zapowiedzi w prawie partykularnym Kościoła katolickiego w Polsce. Zakończenie

\section{Wstęp}

Biorąc pod uwagę wszystkie czynności i obowiązki związane z etapem bezpośredniego przygotowania do małżeństwa temat zapowiedzi przedmałżeńskich nie należy na pewno do najistotniejszych. Co więcej, zgodnie z Kodeksem Prawa Kanonicznego wygłaszanie zapowiedzi nie jest już bezwzględnym obowiązkiem wynikającym $\mathrm{z}$ prawa powszechnego, można bowiem na innej drodze upewnić się, że nic nie stoi na przeszkodzie do ważnego i godziwego zawarcia małżeństwa ${ }^{1}$. Z drugiej jednak strony zawarcie małżeństwa nie jest kwestią jedynie prywatną i publiczne podanie do wiadomości zamiaru jego zawarcia jest głęboko uzasadnione. Ponadto instytucja zapowiedzi zajmuje doniosłe, ważne i wielowiekowe miejsce w ramach

1 Por. Codex Iuris Canonici auctoritate Ioannis Pauli PP. II promulgatus, 25.01.1983, AAS 75 (1983), pars II, s. 1-317 [dalej: KPK], kan. 1066; por. także L. ChiappetTA, Prontuario di diritto canonico e concordatario, Roma 1994, s. 939. 
kanonicznego badania narzeczonych ${ }^{2}$. Zgodnie zaś z wolą Prawodawcy Konferencje Episkopatu mogą wydać w tej kwestii szczegółowe normy ${ }^{3}$. Jak powszechnie wiadomo, w czerwcu bieżącego roku zaczęła obowiązywać tzw. nowa instrukcja Episkopatu Polski o przygotowaniu do zawarcia małżeństwa w Kościele katolickim ${ }^{4}$. W ostatnim czasie uległy zmianie również przepisy regulujące ochronę danych osobowych ${ }^{5}$. Mając więc na uwadze powyższe nowelizacje wydaje się pożyteczne usystematyzowanie aktualnie obowiązujących norm prawnych regulujących kwestię zapowiedzi przedmałżeńskich w Kościele katolickim w Polsce. W niniejszym artykule, chronologicznie, poczynając od Kodeksu Prawa Kanonicznego z 1983 roku, zostaną poddane analizie wszystkie akty prawne, jakie należy obecnie wziąć pod uwagę wygłaszając zapowiedzi.

\section{Zapowiedzi w Kodeksie Prawa Kanonicznego z 1983 roku}

Instytucja zapowiedzi w pierwszym rzędzie łączy się z badaniem stanu wolnego nupturientów, zaś jej podstawy prawne znajdują się w rozdziale I, tytule VII, księgi IV KPK poświęconym pasterskiej

2 Rys historyczny szczegółowo opisuje literatura: por. J. GrĘźLIKowski, Ślubuje Ci... miłość, wierność i uczciwość, Włocławek 2012, s. 80-81; Z. JANCZEWski, Zapowiedzi przedmałżeńskie a prawo do ochrony danych osobowych, Ius Matrimoniale 12 (2007), s. 52-54; J. Dziobek-Romański, Podstawy prawne obowiązku głoszenia zapowiedzi przedślubnych w Kościele, Roczniki Nauk Prawnych 8 (1998), s. 148-152.

3 Por. kan. 1067 KPK.

4 Por. Dekret ogólny o przeprowadzaniu rozmów kanoniczno-duszpasterskich z narzeczonymi przed zawarciem małżeństwa kanonicznego, Akta Konferencji Episkopatu Polski 31 (2019), s. 27-92 (dalej Dekret ogólny o przeprowadzaniu rozmów kanoniczno-duszpasterskich).

${ }^{5}$ Por. Dekret ogólny w sprawie ochrony osób fizycznych w związku z przetwarzaniem danych osobowych w Kościele katolickim wydany przez Konferencję Episkopatu Polski w dniu 13 marca 2018 r. podczas 378. Zebrania Plenarnego w Warszawie, na podstawie kan. 455 Kodeksu Prawa Kanonicznego, w związku z art. 18 Statutu KEP, po uzyskaniu specjalnego zezwolenia Stolicy Apostolskiej z 3 czerwca 2017 r., Akta Konferencji Episkopatu Polski 30 (2018), s. 31-45 (dalej Dekret ogólny o ochronie danych osobowych). 
trosce i czynnościom poprzedzającym zawarcie małżeństwa. Instytucja ta ma jednak również szerszy, społeczny wymiar związany z urzędowym powiadomieniem miejscowej wspólnoty o fakcie mającym niewątpliwie społeczny wydźwięk ${ }^{6}$. Jak podaje J. Gręźlikowski: „Zapowiedzi przedślubne to publiczne obwieszczenie duszpasterskie o zamiarze zawarcia związku małżeńskiego przez określone osoby w najbliższym czasie. Celem zapowiedzi jest wykrycie ewentualnych przeszkód małżeńskich przy pomocy społeczności kościelnej"7. Obecnie obowiązujące normy prawa powszechnego nie nakładają już bezwzględnego obowiązku wygłaszania zapowiedzi. Prawodawca kościelny, w kan. 1066 KPK formułuje bowiem jedynie normę ogólną, zgodnie z którą przed zawarciem małżeństwa należy upewnić się o braku przeszkód do jego ważnego i godziwego zawarcia ${ }^{8}$. Sposoby realizacji tego obowiązku mogą być więc różne. Podmiotami tego przepisu prawnego są ci, na których ciąży obowiązek przeprowadzenia dochodzenia przedmałżeńskiego oraz ci, którzy upoważnieni są do asystowania przy zawieraniu małżeństwa, czyli ordynariusze miejsca oraz proboszczowie. Jak zauważa Z. Janczewski, obowiązujący kodeks nie umniejsza jednak w niczym rangi zapowiedzi przedmałżeńskich, a jedynie nadaje im partykularny charakter ${ }^{9}$. W kolejnym kanonie Prawodawca uszczegóławia bowiem normę ogólną, wyliczając zapowiedzi jako jeden ze środków służących do przeprowadzenia kanonicznego badania narzeczonych, zaś poszczególne Konferencje Episkopatów zobowiązuje do wydania szczegółowych regulacji $\mathrm{w}$ tej materii ${ }^{10}$. Korzystając $\mathrm{z}$ tej prerogatywy Konferencja Episkopatu Polski w listopadzie 2019 roku opublikowała nowy Dekret ogólny

6 Por. E. Sztafrowski, Podręcznik prawa kanonicznego, t. 4, Warszawa 1986, s. 50.

7 J. Gręźlikowski, Ślubuję Ci..., dz. cyt., s. 80.

${ }^{8}$ kan. 1066 KPK: „Antequam matrimonium celebretur, constare debet nihil eius validae ac licitae celebrationi obsistere".

9 Por. Z. Janczewski, Zapowiedzi przedmałżéskie..., dz. cyt., s. 57.

${ }^{10}$ kan. 1067 KPK: „Episcoporum conferentia statuat normas de examine sponsorum, necnon de publicationibus matrimonialibus aliisve opportunis mediis ad investigationes peragendas, quae ante matrimonium necessaria sunt, quibus diligenter observatis, parochus procedere possit ad matrimonio assistendum". 
o przeprowadzaniu rozmów kanoniczno-duszpasterskich z narzeczonymi przed zawarciem małżństwa kanonicznego. Dokument ten zastąpił obowiązujące od trzydziestu lat przepisy zawarte w Instrukcji KEP o przygotowaniu do matżeństwa $w$ Kościele katolickim z 1989 roku $^{11}$. Jak czytamy na oficjalnej stronie KEP: „Celem nowej regulacji jest dostosowanie przepisów prawa partykularnego do nowych wyzwań, z którymi narzeczeni i duszpasterze stykają się w zmieniającej się sytuacji religijnej, społecznej i cywilnoprawnej, z uwzględnieniem m.in. możliwości zawarcia małżeństwa wyznaniowego ze skutkami cywilnymi i nowych przepisów o ochronie osób fizycznych w związku z przetwarzaniem danych osobowych, jak również owoców obrad Synodu Biskupów na temat małżeństwa i rodziny oraz adhortacji papieża Franciszka Amoris laetitia"12.

Szczegółowe regulacje znowelizowanego prawa partykularnego w zakresie zapowiedzi przedmałżeńskich przedstawione zostaną w dalszej części niniejszego artykułu. W tym miejscu, kontynuując analizę przepisów prawa powszechnego, wspomnieć należy jeszcze o dwóch przepisach prawnych. Zgodnie z kan. 1069 KPK wierni, mający wiedzę na temat przeszkód małżeńskich co do danego małżeństwa, które ma być zawarte, mają obowiązek wyjawić ją wobec właściwego ordynariusza miejsca lub proboszcza, oczywiście przed jego zawarciem ${ }^{13}$. Przepis ten ściśle wiąże się z zapowiedziami, gdyż to na ich podstawie ogół wiernych danej wspólnoty lub wspólnot parafialnych dowiaduje się o zamiarze zawarcia małżeństwa przez określonych nupturientów. Jak podkreślają komentatorzy, obowiązek wynikający z tego kanonu jest na tyle ważny, iż należy o nim pouczać swoich parafian ${ }^{14}$. Na zakończenie niniejszej części wspomnieć

11 Por. Instrukcja Konferencji Episkopatu Polski o przygotowaniu do zawarcia małżeństwa w Kościele katolickim, Kraków 1990.

12 https://episkopat.pl/nowe-przepisy-o-kanonicznym-przygotowaniu-do-malzenstwa/ (dostęp: 19.12.2020 r.).

13 kan. 1069 KPK: „Omnes fideles obligatione tenentur impedimenta, si quae norint, parocho aut loci Ordinario, ante matrimonii celebrationem, revelandi”.

14 Por. W. Góralski, Małżeństwo, w: J. Krukowski (red.), Komentarz do Kodeksu Prawa Kanonicznego, t. III/2, Poznań 2011, s. 266. 
również należy, iż zgodnie z kan. $88 \mathrm{KPK}$ ordynariusz miejsca, dla dobra wiernych, może dyspensować od ustaw wydanych przez Konferencję Episkopatu ${ }^{15}$. Norma ta ma zastosowanie także w materii zapowiedzi przedmałżeńskich.

\section{Ochrona danych osobowych}

Z zapowiedziami przedmałżeńskimi nieodzownie związany jest obecnie temat ochrony danych osobowych. Temat ten stał się w ostatnim czasie przedmiotem licznych opracowań i wypowiedzi, także w Kościele katolickim ${ }^{16}$. Związane jest to $\mathrm{z}$ trudnością wyważenia właściwej proporcji pomiędzy prywatnością osoby indywidualnej a życiem społecznym; pomiędzy swobodą działania Kościoła katolickiego na podstawie przepisów prawa kanonicznego a jednoczesnym funkcjonowaniem w obszarze ustawodawstwa cywilnego. Jak zauważa A. Domaszk, prawo do prywatności nie wydaje się być prawem absolutnym, należy bowiem dostrzec prawo wspólnoty religijnej do zachowania własnych tradycji prawnych ${ }^{17}$. Zgodnie z art. 5 Konkordatu z 1993 roku Państwo Polskie gwarantuje co prawda Kościołowi katolickiemu swobodne i publiczne pełnienie swojej misji, łącznie $\mathrm{z}$ wykonywaniem jurysdykcji oraz zarządzaniem i administrowaniem swoimi sprawami zgodnie z przepisami prawa kanonicznego, nie oznacza to jednak bezwzględnej autonomii działania ${ }^{18}$.

15 kan. 88 KPK: „Ordinarius loci in legibus dioecesanis atque, quoties id ad fidelium bonum conferre iudicet, in legibus a Concilio plenario vel provinciali aut ab Episcoporum conferentia latis dispensare valet".

16 Dla przykładu podać można następujące pozycje: A. DomAszk, Ochrona danych osobowych - obowiazek duszpasterski, Prawo Kanoniczne 53 (2010) nr 3-4, s. 43-67;

S. DzIEKoński, P. Drabek (red.), Ochrona danych osobowych w Kościele, Warszawa 2016; S. JanCZEwski, Zapowiedzi przedmatżeńskie, dz. cyt., s. 51-66; P. MaJER (red.), Ochrona danych osobowych i prawo do prywatności w Kościele, Kraków 2002.

17 Por. A. Domaszk, Ochrona danych osobowych w Polsce a Kościół katolicki, Seminare 40 (2019) nr 1, s. 34.

18 Por. Konkordat między Stolica Apostolską i Rzeczpospolitą Polską, Dziennik Ustaw z 1998 r., nr 51, poz. 318, art. 5. 
Pomijając w tym miejscu szczegółową analizę rozwoju ustawodawstwa kościelnego i cywilnego w materii przetwarzania danych osobowych konieczne jest jednak przedstawienie ogólnego zarysu problemu, wraz z obowiązującymi obecnie przepisami prawnymi. „Od 25 maja 2018 r. w Polsce obowiązuje rozporządzenie Parlamentu Europejskiego i Rady Unii Europejskiej z 27 kwietnia 2016 r. w sprawie ochrony osób fizycznych w związku z przetwarzaniem ich danych osobowych i w sprawie swobodnego przepływu takich danych (...). W ramach tzw. vacatio legis państwa unijne miały obowiązek dostosować swoje wewnętrzne prawo w zakresie przetwarzania danych osobowych do wskazanego dokumentu. Obowiązek ten spoczywał także na kościołach i związkach wyznaniowych, z uwzględnieniem i poszanowaniem ich autonomii"19. Podstawowym aktem prawa polskiego obowiązującym obecnie w materii ochrony danych osobowych jest ustawa $\mathrm{z}$ 10.05.2018 $\mathrm{roku}^{20}$. Zastąpiła ona wcześniejszą ustawę na ten temat z 1997 roku. Zaś w obszarze prawa kościelnego KEP 13.03.2018 roku wydała Dekret ogólny w sprawie ochrony osób fizycznych $w$ związku z przetwarzaniem danych osobowych $w$ Kościele katolickim. Zastąpił on instrukcję z 2009 roku. Zgodnie z art. 91, ust. 1 wspomnianego już wyżej rozporządzenia Parlamentu Europejskiego i Rady Unii Europejskiej z 27.04.2016 roku Kościół katolicki w Polsce nadal ma możliwość stosowania odrębnych regulacji o ochronie danych osobowych, o ile takie posiadał w chwili wejścia w życie powyższego rozporządzenia oraz o ile są one zgodne $\mathrm{z}$ jego treścią ${ }^{21}$.

\footnotetext{
19 A. Domaszk, Ochrona danych osobowych w Polsce a Kościół katolicki, Seminare 40 (2019) nr 1, s. 24.

20 Ustawa z 10 maja 2018 r. o ochronie danych osobowych, Dziennik Ustaw z 2018 r., poz. 1000.

21 Art. 91, ust. 1 Rozporządzenia Parlamentu Europejskiego i Rady Unii Europejskiej z 27 kwietnia 2016 r. w sprawie ochrony osób fizycznych w związku z przetwarzaniem ich danych osobowych $i$ w sprawie swobodnego przepływu takich danych: „Jeżeli w państwie członkowskim w momencie wejścia niniejszego rozporządzenia w życie kościoły i związki lub wspólnoty wyznaniowe stosują szczegółowe zasady ochrony osób fizycznych w związku z przetwarzaniem, zasady takie mogą być nadal stosowane, pod warunkiem że zostaną dostosowane do niniejszego rozporządzenia”,
} 
Na podstawie niniejszego przepisu, mając na uwadze powyżej przedstawioną chronologię ukazywania się dokumentów kościelnych oraz cywilnych, obowiązującym obecnie w Kościele katolickim w Polsce aktem prawnym dotyczącym ochrony danych osobowych jest wspomniany wyżej dekret ogólny z 13.03.2018 roku. Zgodnie z jego treścią przez dane osobowe rozumie się „informacje o zidentyfikowanej lub możliwej do zidentyfikowania osobie fizycznej (...); możliwa do zidentyfikowania osoba fizyczna to osoba, którą można bezpośrednio lub pośrednio zidentyfikować, w szczególności na podstawie identyfikatora takiego jak imię i nazwisko, numer identyfikacyjny, dane o lokalizacji, identyfikator internetowy lub jeden bądź kilka szczególnych czynników określających fizyczną, fizjologiczną, genetyczną, psychiczną, ekonomiczną, kulturową lub społeczną tożsamość osoby fizycznej"22. Przetwarzanie danych osobowych oznacza „operację lub zestaw operacji wykonywanych na danych osobowych lub zestawach danych osobowych w sposób zautomatyzowany lub niezautomatyzowany"23. Naruszenie ochrony danych osobowych zdefiniowane zaś zostało jako: „naruszenie bezpieczeństwa prowadzące do przypadkowego lub niezgodnego z prawem zniszczenia, utracenia, zmodyfikowania, nieuprawnionego ujawnienia lub nieuprawnionego dostępu do danych osobowych przesyłanych, przechowywanych lub w inny sposób przetwarzanych"24. Mając powyższe definicje na uwadze, nie ulega wątpliwości, że wygłaszanie zapowiedzi jest przetwarzaniem danych osobowych. Wobec tego rodzi się pytanie, w jaki sposób dekret KEP odnosi się do zapowiedzi przedmałżeńskich oraz, czy nupturienci muszą wyrazić na nie zgodę? Dekret ogólny nie reguluje tej kwestii wprost, natomiast formułuje normy ogólne, które mają swoje zastosowanie w interesującym nas temacie. Zgodnie z art. 7 dekretu: „W działalności publicznych kościelnych

\footnotetext{
https://eur-lex.europa.eu/legal-content/PL/TXT/PDF/?uri=CELEX:32016R0679, (dostęp 19.12.2020 r.).

22 Dekret ogólny o ochronie danych osobowych, art. 5.1.

23 TAMŻE, art. 5.2.

24 TAMŻE, art. 5.8.
} 
osób prawnych przetwarzanie danych osobowych jest dopuszczalne, jeżeli (...) przetwarzanie jest niezbędne do wypełnienia obowiązku prawnego ciążącego na administratorze, zgodnie z przepisami prawa kanonicznego lub prawa świeckiego”25. Ponadto, „przetwarzanie danych wrażliwych dopuszczalne jest wyłącznie w stosunku do osób ochrzczonych w Kościele katolickim i tych, którzy po chrzcie zostali do niego przyjęci (członków Kościoła), łącznie z tymi, którzy złożyli formalne oświadczenie woli o wystąpieniu z Kościoła katolickiego, zgodnie z wewnętrznymi przepisami Kościoła („byłych członków Kościoła”) oraz osób utrzymujących z nim stałe kontakty w związku z realizacją celów Kościoła w ramach uprawnionej działalności prowadzonej z zachowaniem odpowiednich zabezpieczeń. Dane te nie są ujawniane poza Kościołem bez zgody osób, których dane dotyczą"26. Zgoda na przetwarzanie danych osobowych, w tym również na wygłoszenie zapowiedzi, byłaby więc wymagana jedynie wtedy, gdy dane te były ujawniane poza Kościołem. Tak się jednak nie dzieje. Reasumując powyższą analizę, stwierdzić należy, że proboszcz zobowiązany jest oczywiście do ochrony danych osobowych, nie musi jednak prosić o specjalną zgodę na wygłaszanie zapowiedzi. Ten akt prawny jest bowiem wykorzystywany w ramach przedmałżeńskiego badania nupturientów, do przeprowadzenia którego proboszcz jest zobligowany przepisami prawa kanonicznego.

\section{Zapowiedzi w prawie partykularnym Kościoła katolickiego w Polsce}

Jak zostało wspomniane już wyżej, na mocy kan. 1067 KPK oraz kan. $455 \$ 1 \mathrm{KPK}^{27}$, po rekognicji Stolicy Apostolskiej, KEP

\footnotetext{
25 TAMŻE, art. 7.1.3.

26 TAMŻE, art. 7.2.

27 kan. $455 \$ 1$ KPK: „Episcoporum conferentia decreta generalia ferre tantummodo potest in causis, in quibus ius universale id praescripserit aut peculiare Apostolicae Sedis mandatum sive motu proprio sive ad petitionem ipsius conferentiae id statuerit".
} 
promulgowała dnia 26.11.2019 roku Dekret ogólny o przeprowadzaniu rozmów kanoniczno-duszpasterskich z narzeczonymi przed zawarciem małżeństwa kanonicznego. Na mocy uchwały nr 9/385/2019 KEP z 18.11.2019 roku określono termin wejścia w życie niniejszego dekretu na dzień 1.06.2020 roku. W porównaniu z obowiązującą do 1.06.2020 roku Instrukcją KEP o przygotowaniu do małżeństwa w Kościele katolickim Prawodawca w nowym dekrecie poświęcił więcej miejsca na omówienie kwestii związanych z zapowiedziami przedmałżeńskimi.

W art. 14 określony został cel zapowiedzi przedmałżeńskich. Oczywiście jest on zbieżny z tym, o czym była już mowa wcześniej: wykrycie ewentualnych przeszkód do zawarcia danego małżeństwa oraz powiadomienie lokalnej wspólnoty o planowanym małżeństwie. Nowością dekretu jest natomiast zobligowanie duszpasterzy do połączenia zapowiedzi przedmałżeńskich z modlitwą za narzeczonych ${ }^{28}$.

Pierwsza część art. 15, określająca sposób ogłaszania zapowiedzi, jest właściwie tożsama $\mathrm{z}$ dotąd obowiązującą normą ${ }^{29}$. Zapowiedzi przedmałżeńskie ogłasza się pisemnie, przez umieszczenie w gablocie parafialnej w ciągu ośmiu dni, tak, by były uwidocznione przynajmniej przez dwie kolejne niedziele, lub niedzielę i święto, lub ustnie,

28 Dekret ogólny o przeprowadzaniu rozmów kanoniczno-duszpasterskich, art. 14: „Zamierzone małżeństwo, które nie jest sprawą prywatną, ale społeczną, należy ogłosić w parafiach aktualnego zamieszkania narzeczonych. Celem głoszenia zapowiedzi jest powiadomienie o planowanym małżeństwie wspólnoty parafialnej, a także stworzenie możliwości, by wierni mogli wyjawić ewentualne znane im przeszkody sprzeciwiające się zawarciu danego małżeństwa. Publikowanie zapowiedzi należy połączyć z modlitwą wspólnoty parafialnej za przygotowujących się do małżeństwa (np. w modlitwie wiernych)".

${ }^{29}$ Dekret ogólny o przeprowadzaniu rozmów kanoniczno-duszpasterskich, art. 15: „Zapowiedzi ogłasza się w formie pisemnej przez umieszczenie ich w gablocie ogłoszeń parafialnych w ciągu ośmiu dni, tak by były tam uwidocznione przynajmniej przez dwie kolejne niedziele, lub w niedzielę i święto obowiązujące. Ten sam obowiązek można spełnić przez ogłoszenie ustne podczas liczniej uczęszczanych nabożeństw parafialnych, w kolejne dwie niedziele lub w niedzielę i święto obowiązujące. Do wiadomości - zarówno w formie ustnej, jak i pisemnej - podaje się jedynie imiona i nazwiska oraz parafię zamieszkania tych, którzy mają zamiar zawrzeć małżeństwo”. 
odczytując je podczas licznie uczęszczanych nabożeństw w kolejne dwie niedziele lub niedzielę i święto. Ważnym dodatkiem jest natomiast wskazanie, jakie dane należy podać do wiadomości wiernych. Zgodnie z nowym dekretem w zapowiedziach należy ogłosić jedynie imiona i nazwiska oraz parafię zamieszkania nupturientów. To spora różnica, biorąc pod uwagę chociażby jeden z najbardziej popularnych formularzy stosowany jeszcze przed nowelizacją, w którym prócz imienia i nazwiska znajdowało się miejsce na wpisanie: imienia ojca, miejsca i daty urodzenia, stanu cywilnego, wyznania, zawodu oraz adresu. Jak łatwo się domyślić, tak znacząca zmiana w samej materii zapowiedzi podyktowana została względami prawnymi wynikającymi z konieczności dostosowania prawa kościelnego do wymogów prawa cywilnego w zakresie przetwarzania danych osobowych. Jak zauważa P. Majer zmiana ta wywołała jednak sporo dyskusji. Uważa się bowiem, że realna możliwość identyfikacji nupturientów jedynie na podstawie imienia, nazwiska i parafii jest co najmniej utrudniona, a w środowisku wielkomiejskim wręcz niemożliwa. Podaje to w wątpliwość przydatność instytucji zapowiedzi przedmałżeńskich jako takich ${ }^{30}$. Pomimo zasadności tych wątpliwości przepis prawny wszedł w życie niezmieniony, należy go więc stosować, obserwując jednocześnie jego implikacje. Mając zaś na uwadze praktykę duszpasterską, która jak wiadomo czasem odbiega od obowiązujących norm prawnych, należy z tym większą stanowczością uświadamiać proboszczom treści nowego przepisu, a także uczulać ich na konieczność przestrzegania przepisów prawnych z zakresu ochrony danych osobowych. W obecnych czasach jest to temat bardzo ważki i nie należy go lekceważyć.

W kolejnym artykule dekretu mowa jest przede wszystkim o miejscu wygłaszania zapowiedzi ${ }^{31}$. Warto jednak zauważyć, że

30 Por. P. Majer, Prace Konferencji Episkopatu Polski nad nowa regulacja przygotowania do zawarcia małżeństwa kanonicznego (cz. I), Biuletyn Stowarzyszenia Kanonistów Polskich 29 (2019) nr 22, s. 148.

31 Dekret ogólny o przeprowadzaniu rozmów kanoniczno-duszpasterskich, art. 16: „Obowiązek wygłoszenia zapowiedzi ma proboszcz aktualnego zamieszkania 
Prawodawca najpierw nakłada na proboszczów obowiązek wygłaszania zapowiedzi. Podobnie jak w prawie powszechnym, nie jest to obowiązek bezwzględny, chociaż sformułowanie art. 16 dekretu jest kategoryczne. Co się zaś tyczy miejsca wygłoszenia zapowiedzi, nowy dekret generalnie podtrzymuje ustalenia poprzedniej instrukcji, w niektórych jednak przypadkach poszerzając obszar ich wygłaszania. I tak, jeśli nupturienci mieszkają na terenie parafii krócej niż sześć miesięcy, prośbę o wygłoszenie zapowiedzi należy wysłać nie tylko do poprzedniej parafii, ale do wszystkich, w których mieli oni stałe zamieszkanie po osiągnięciu pełnoletności. Art. 16 dekretu wyszczególnia także inne, specyficzne sytuacje: chrześcijan niekatolików; nieochrzczonych; tych, którzy wystąpili z Kościoła katolickiego; katolików mieszkających za granicą, w diecezji, w której prawo partykularne nie przewiduje wygłaszania zapowiedzi. Jedynie w pierwszym z wymienionych przypadków prosi się o wygłoszenie zapowiedzi, jeśli wymagają tego wewnętrzne przepisy danej wspólnoty religijnej, w pozostałych nie wygłasza się zapowiedzi.

Art. 17 dekretu reguluje kwestie formalne związane $\mathrm{z}$ wystąpieniem do innej parafii z prośbą o wygłoszenie zapowiedzi ${ }^{32}$. Warto

każdej ze stron (por. kan. $102 \$ 1$ ). Jeżeli narzeczeni mieszkają w parafii krócej niż sześć miesięcy, zapowiedzi należy wygłosić także w poprzednim miejscu (lub miejscach) stałego zamieszkania nupturientów po osiągnięciu przez nich pełnoletności. W przypadku chrześcijan niekatolików mieszkających w Polsce należy zwrócić się do ich właściwych pasterzy o wygłoszenie zapowiedzi, jeżeli tego wymaga prawo własne wspólnoty religijnej, do której należą. Nie publikuje się zapowiedzi w miejscu zamieszkania nupturientów nieochrzczonych oraz tych, którzy wystąpili z Kościoła katolickiego. Nie prosi się o publikację zapowiedzi także w przypadku nupturientów katolików, którzy mają zamieszkanie kanoniczne w diecezji za granicą, w której według własnego prawa partykularnego nie publikuje się zapowiedzi”.

32 Dekret ogólny o przeprowadzaniu rozmów kanoniczno-duszpasterskich, art. 17: „Jeśli zapowiedzi mają być głoszone w innej parafii niż ta, w której jest spisywany protokół przedślubny, proboszcz winien zwrócić się z pisemną prośbą o ich wygłoszenie (formularz 6). Gdy to zostanie dokonane, właściwy proboszcz powiadamia na piśmie o wygłoszeniu zapowiedzi, ewentualnych zgłoszeniach przeszkód lub ich braku, parafię, w której odbywa się badanie kanoniczne narzeczonych. Fakt wygłoszenia zapowiedzi i ich rezultat należy udokumentować w księdze zapowiedzi”. 
w tym miejscu podkreślić, że nowy dekret zawiera załączniki, wśród których jeden dotyczy poruszanej kwestii.

Ostatni artykuł z części poświęconej zapowiedziom traktuje o możliwości zwolnienia z obowiązku ich wygłaszania ${ }^{33}$. Kompetentnym pozostaje ordynariusz miejsca, zaś wśród przykładowych przyczyn ubiegania się o dyspensę wylicza się: dobro duchowe stron; uważnienie już zawartego małżeństwa; niebezpieczeństwo zawarcia małżeństwa nieważnego; dobro dziecka nienarodzonego; omnia parata ad nuptias; zaawansowany wiek nupturientów ${ }^{34}$.

\section{Zakończenie}

Podsumowując, na pierwszym miejscu należy zauważyć względy formalne związane $\mathrm{z}$ wyższą rangą nowego dokumentu KEP. Nowe prawo partykularne w zakresie przygotowania do zawarcia małżeństwa kanonicznego promulgowane zostało jako dekret ogólny, czyli jako ustawa, w odróżnieniu do wcześniej obowiązującej instrukcji. Podnosi to walor obowiązujących przepisów, co jednocześnie ułatwia ich egzekwowanie. Po drugie docenić należy dostosowanie do wymogów prawa cywilnego, europejskiego i krajowego, norm prawnych dotyczących zapowiedzi w zakresie ochrony danych osobowych. Kwestią otwartą pozostaje natomiast skuteczność stosowania zapowiedzi w obecnej formie. Wydaje się, iż temat ten wymaga dalszych analiz, co może stać się przyczynkiem do kontynuowania niniejszych

${ }^{33}$ Dekret ogólny o przeprowadzaniu rozmów kanoniczno-duszpasterskich, art. 18: „Ordynariusz miejsca w uzasadnionych przypadkach może zwolnić z obowiązku ogłaszania zapowiedzi (formularz 6a). Można, a w niektórych przypadkach wręcz powinno się skorzystać z tej możliwości, jeśli przedłożone dokumenty nie budzą wątpliwości co do stanu wolnego i braku innych przeszkód małżeńskich pomiędzy nupturientami, a ogłaszanie zapowiedzi powodowałoby dla nich dużą niedogodność (np. obawa zniesławienia w sytuacji, gdy mieszkający ze sobą od dłuższego czasu nupturienci w społeczności wiernych uchodzili za małżeństwo albo sytuacja osób po kanonicznym stwierdzeniu nieważności poprzedniego małżeństwa)”. ${ }^{34}$ Por. Dekret ogólny o przeprowadzaniu rozmów kanoniczno-duszpasterskich, formularz $6 a$. 
rozważań. Pewne rozwiązanie podsuwa jednak literatura i to wcale nie ta najnowsza. Jak zauważa F. Gil de las Heras problem nieskuteczności zapowiedzi jako środka do stwierdzenia braku przeszkód do zawarcia małżeństwa nie jest wcale nowy i wynika on z praktyki duszpasterskiej. Jeśli bowiem proboszcz ogranicza się jedynie do wyczytania lub wywieszenia zapowiedzi w gablocie parafialnej ich skuteczność rzeczywiście jest znikoma, gdyż niewielu wiernych się tym zainteresuje. Wspomniany wyżej autor postuluje więc, by duszpasterz, wygłaszając zapowiedzi poświęcił kilka minut na przedstawienie i wyjaśnienie przeszkód małżeńskich i wad zgodny małżeńskiej, tak, by wierni mieli świadomość prawdziwego celu ich wygłaszania ${ }^{35}$. Postulat ten wydaje się być zasadny i pożyteczny. Ponadto, mając na względzie wspomnianą wyżej powinność połączenia zapowiedzi przedmałżeńskich $\mathrm{z}$ modlitwą za osoby przygotowujące się do zawarcia małżeństwa, wygłaszanie zapowiedzi może stać się szansą przepowiadania duszpasterskiego oraz upowszechniania wiedzy na temat prawnych aspektów małżeństwa.

\section{The institution of the examination of spouses in the current legal order of the Catholic Church in Poland}

\section{Summary}

According to can. 1067 of the Code of Canon Law „The Episcopal Conference should issue norms relating the examination of spouses, the marriage banns and other opportune means to accomplish the investigations necessary before marriage, so that the parish priest, following them diligently, may assist in the marriage". Taking into account the legal norms regarding preparation for marriage and the protection of personal data amended by the Polish Bishops' Conference, this article systematizes the topic of premarital announcements in the current legal order of the Catholic Church in Poland.

${ }_{35}$ Por. F. Gil de las Heras, Valutazione della capacità per sposarsi nell'ammissione al matrimonio, w: M.A. Ortiz (red.), Ammissione alle nozze e prevenzione della nullità del matrimonio, Milano 2005, s. 86-87. 
Słowa kluczowe: badanie przedślubne narzeczonych, zapowiedzi, przygotowanie do małżeństwa

Key words: the examination of spouses, the marriage banns, preparation for marriage

Nota o autorze

Ks. Rafał Dappa - doktor prawa kanonicznego, adiunkt na Wydziale Teologicznym Uniwersytetu Śląskiego w Katowicach, wiceoficjał Sądu Biskupiego Diecezji Gliwickiej 